\title{
Links between Arbuscular Mycorrhizal Fungal and Nitrogen-Fixing Bacterial Communities from Plant Rhizosphere Soils in the Karst Region of Southwest China
}

\author{
Yueming Liang ${ }^{2}$, Yirong Su ${ }^{1,3}$, Xiangbi Chen ${ }^{1,3}$, Fujing Pan ${ }^{4}$, Xunyang He $\mathrm{He}^{1,3 *}$ \\ ${ }^{1}$ Key Laboratory of Agro-Ecological Processes in Subtropical Region, Institute of Subtropical Agriculture, \\ Chinese Academy of Sciences, China \\ ${ }^{2}$ Institute of Karst Geology, CAGS, Karst Dynamics Laboratory, MLR, China \\ ${ }^{3}$ Huanjiang Observation and Research Station for Karst Eco-systems, Chinese Academy of Sciences, Huanjiang, China \\ ${ }^{4}$ College of Environmental Science and Engineering, Guilin University of Technology, China
}

Received: 2 June 2021

Accepted: 10 September 2021

\begin{abstract}
Arbuscular mycorrhizal (AM) fungi and nitrogen-fixing bacteria (NFB) are critical to plant growth and recovery in degraded ecosystems. However, information about the relationships between these microorganisms in the rhizosphere soils of natural ecosystems is limited. Rhizosphere soils from six common plant species: (Loropetalum chinense, Syzygium championii, Alchornea trewioides, Bauhinia purpurea, Pterolobium punctatum and Albizia odoratissima), were sampled in the karst region of Southwest China. The abundance and community composition of AM fungi and NFB were measured using quantitative polymerase chain reaction (qPCR) and terminal restriction fragment length polymorphism (T-RFLP). The community composition and abundance of AM fungi and NFB varied among plant rhizosphere soils, but the richness of these microbes was not significantly different. The abundances of AM fungi and NFB significantly related to each other. Specifically, dominant 278-bp and 105-bp terminal restriction fragments (T-RFs) of AM fungi positively linked with dominant 184-bp and 180-bp T-RFs of NFB $(P<0.05)$, respectively. Redundant analyses indicated that soil organic carbon, available phosphorus, and total nitrogen significantly correlated with the composition of fungal and bacterial communities. These results suggest that AM fungi and NFB have host-plant specificity and that these microbes are closely linked in plant rhizosphere soils of the karst region.
\end{abstract}

Keywords: arbuscular mycorrhizal fungi, nitrogen-fixing bacteria, soil microbial diversity, karst, rhizosphere

*e-mail: hbhpjhn@isa.ac.cn 


\section{Introduction}

The soil microbial community is critical for plant growth and development. In particular, two major groups of rhizosphere microbes, arbuscular mycorrhizal (AM) fungi and nitrogen-fixing bacteria (rhizobia), increase the supply of nitrogen, phosphorus, and other essential nutrients to plants [1-3], thus, promoting their establishment in a given soil habitat. Moreover, AM fungi strengthen the physical composition of soil by stabilizing soil aggregate structure [4]. Thus, these microbes play major complementary roles in the successful recolonization of plants in severely disturbed soil systems by establishing a sustainable nutrients cycle and improving soil stabilization [5].

Given that their beneficial effects both derive from altering soil properties to improve nutrient uptake, the two microbial taxa may act synergistically in promoting plant growth. For example, increased phosphorus uptake stemming from the action of AM fungi yields more energy for rhizobia to fix nitrogen [6]. Indeed, co-inoculation with AM fungi and NFB appeared to stimulate plant growth and biomass increase [2, 3, 7], more so than either inoculation with AM fungi or NFB alone [2]. However, other experiments have yielded inconsistent results. Larimer et al. [8] reported that rhizobia inoculation suppresses AM fungal colonization of roots, even though AM fungal infection increases root nodule number and plant mass. Additionally, these two microbial taxa were not synergy due to plants did not perform better than expected given symbiont individual effects $[9,10]$. As can be seen from these results, no clear consensus exists on the relationship between AM fungi and NFB at the species level. Furthermore, most of the studies examining the interaction of these symbiotic microorganisms are usually controlled pot experiments, with few field studies that validate laboratory findings. The lack of field data is particularly notable in soil-nutrient deficient ecosystems, which are especially dependent on AM fungi and rhizobia for plant growth.

Karst landscapes are ideal for such field research because the soil nutrient content is considerably lower than other regions at the same latitude [11] and is easily lost due to the prominent underground drainage system characteristic of this topography [12, 13]. The karst region of Southwest China, one of the largest in the world, covers $540000 \mathrm{~km}^{2}$ [14]. These regions are characterized as low vegetation cover and a high ratio of bedrock outcrop to shallow soil. These features cause the region's ecological systems to be fragile and extremely vulnerable to human activities. Recently, an increasing human population and the resultant over-exploitation of natural resources have accelerated desertification [15]. In response, local Chinese governments have begun to promote ecological restoration of karst regions, and successful recovery is currently evaluated based on the degree of plant establishment [16]. Dominant plant and legume are widely used for vegetation restoration.
However, the relationships between AM fungi and NFB from plants rhizosphere soils in the karst region are poor, although these two microbial taxa have confirmed the benefits of AM fungi and NFB on plant establishment in poor environmental conditions based on pot experiments.

In this study, we hypothesized that a high abundance of AM fungi will be associated with a high abundance of NFB in rhizosphere soils of the Chinese karst region. Our objectives were 1) to characterize AM fungal and NFB communities in rhizosphere soils from six typical plant species of a karst shrub ecosystem and 2) to explore the relationships between AM fungal and NFB communities.

\section{Materials and Methods}

\section{Study Site and Sample Collection}

The study site is located in Huanjiang County, in the Guangxi autonomous region of southwest China $\left(107^{\circ} 51^{\prime}\right.$ to $108^{\circ} 43^{\prime} \mathrm{E}, 24^{\circ} 44^{\prime}$ to $\left.25^{\circ} 33^{\prime} \mathrm{N}\right)$. This region is dominated by a subtropical mountainous monsoon climate, with a mean annual rainfall of $1,389 \mathrm{~mm}$ and a mean annual air temperature of $18.5^{\circ} \mathrm{C}$. The wet season, during which $70 \%$ of the annual precipitation occurs, lasts from April to August [17].

Six representative shrub species: Loropetalum chinense (Hamamelidaceae), Syzygium championii (Myrtaceae), Alchornea trewioides (Euphorbiaceae), Bauhinia purpurea (Leguminosae), Pterolobium punctatum (Leguminosae), and Albizia odoratissima (Leguminosae), were selected in each plot. Loropetalum chinense, S. championii, and A. trewioides were defined as the dominant species, whereas $B$. purpurea, $P$. punctatum, and $A$. odoratissima were considered nondominant and leguminous plants [18]. Considering the higher spatial heterogeneity of soil nutrients in karst ecosystems, plots were established and located in the same topographic position (southeast aspect and middle slope) and rock type (dolomites).

The rhizosphere soils were sampled as previously described by Bell et al. [19] in December 2011. Five individual rhizosphere soils of each host plant in each plot $(10 \mathrm{~m} \times 10 \mathrm{~m})$ were carefully excavated, collected, and thoroughly mixed to form a composite soil sample (18 samples in total: 6 plant species $\times 3$ sampling plots). Because plant age influences AM fungal community composition, we attempted to select plants of comparable age, based on similar basal diameter (approximately $2 \mathrm{~cm}$ ). Additionally, to minimize the effects between hosts, plants were separated by approximately $50 \mathrm{~cm}$. We confirmed that the plants could form nodules when rhizosphere soils were sampled. Each composite soil sample was divided into two subsamples. One subsample was frozen in liquid nitrogen and transported to the laboratory for molecular analysis; the other was air-dried for analysis of soil 
physicochemical properties. The field study sites did not involve any privately-owned land or protected area of land (such as national park), and the sampling did not involve any endangered or protected species. Thus, no specific permits were required for the study field sites.

\section{Soil Physicochemical Properties}

Total nitrogen (TN), available phosphorus (P), soil organic carbon (SOC), and $\mathrm{pH}$ were measured. Soil $\mathrm{pH}$ was determined using a solution of soil and distilled water $(1: 2.5 \mathrm{w} / \mathrm{v})$. We measured SOC using $\mathrm{K}_{2} \mathrm{Cr}_{2} \mathrm{O}_{7} \cdot \mathrm{H}_{2} \mathrm{SO}_{4}$ oxidation-reduction titration and TN using the Kjeldahl method [20]. Available $\mathrm{P}$ was extracted using $0.5 \mathrm{M}$ sodium bicarbonate and measured using the Mo-Sb colorimetric method [21]. Soil physicochemical properties are shown in Table 1.

\section{DNA Extraction from Soil}

Microbial DNA was extracted in triplicate from $500 \mathrm{mg}$ of freeze-dried soil, following the methods of a previous study [17]. The extracted DNA was dissolved in $50 \mu \mathrm{L}$ water, quantified by spectrophotometry, and stored at $-20^{\circ} \mathrm{C}$ until further use. Prior to realtime quantitative polymerase chain reaction (qPCR), the DNA template was prepared by diluting the solution to a final concentration of approximately $5 \mathrm{ng}$ DNA $\mu \mathrm{L}^{-1}$ using sterilized water.

\section{PCR Amplification and Terminal Restriction Fragment Length Polymorphism (T-RFLP) Analyses}

The composition of the AM fungal and NFB communities in the 18 soil samples was estimated with terminal restriction fragment length polymorphism (T-RFLP) analysis. The extracted DNA was subjected to nested PCR with primers Geo11F/GeoA2R and NS31/AM1 (Table 2) for amplification of an $18 \mathrm{~S}$ rRNA gene fragment of AM fungi. The latter forward primer was labeled at the $5^{\prime}$ ends with 6-carboxyfluorescein (FAM; Invitrogen, China). The first PCR $(50-\mu \mathrm{L}$ volume) of Geo11F/GeoA2R contained $25 \mu \mathrm{L} 2 \times$ PCR Premix (0.1 U Prime STAR HS DNA polymerase, $0.5 \mathrm{mM}$ dNTPs; Tiangen, China), $10 \mathrm{pM}$ of each primer, $20 \mathrm{ng}$ genomic DNA, and $19 \mu \mathrm{L} \mathrm{\textrm {H } _ { 2 }} \mathrm{O}$. The cycling conditions were as follows: $95^{\circ} \mathrm{C}$ for $2 \mathrm{~min}$, 35 cycles of $60 \mathrm{~s}$ at $94^{\circ} \mathrm{C}, 60 \mathrm{~s}$ at $60^{\circ} \mathrm{C}$, and $60 \mathrm{~s}$ at $72^{\circ} \mathrm{C}$, followed by $72^{\circ} \mathrm{C}$ for $10 \mathrm{~min}$. The first amplification product was diluted with double-distilled water (1:10) and a $1-\mu \mathrm{L}$ subsample was used as a template for the second PCR amplification under the same conditions, with the following exceptions: 30 PCR cycles were performed instead of 35 and the annealing temperature was $64^{\circ} \mathrm{C}$ instead of $60^{\circ} \mathrm{C}$.

The PolF/PolR primer set was used to amplify the NFB nifH gene (Table 2). The reaction was performed in a $50-\mu \mathrm{L}$ volume with $25 \mu \mathrm{L} 2 \times$ PCR Premix (0.1 U Prime STAR HS DNA polymerase, $0.5 \mathrm{mM}$ dNTPs), $10 \mathrm{pM}$ of each primer, $20 \mathrm{ng}$ genomic DNA, and $19 \mu \mathrm{L} \mathrm{H}_{2} \mathrm{O}$. Cycling conditions for the nifH gene were an initial denaturation step at $95^{\circ} \mathrm{C}$ for $2 \mathrm{~min}$, 35 cycles at $94^{\circ} \mathrm{C}$ for $30 \mathrm{~s}, 55^{\circ} \mathrm{C}$ for $60 \mathrm{~s}$, and $72^{\circ} \mathrm{C}$ for $60 \mathrm{~s}$, followed by a final 10 -min extension at $72^{\circ} \mathrm{C}$.

Triplicate reaction mixtures per sample were pooled, purified using the QIAquick PCR purification kit (Tiangen Biotech Ltd., China), and quantified using NanoDrop ND-1000 (Thermo Scientific, USA). Approximately $200 \mathrm{ng}$ of each amplicon was digested with $5 \mathrm{U}$ restriction enzyme. Restriction enzymes HinfI and HaeIII were used to digest the fungal $18 \mathrm{~S}$ rRNA gene and the bacterial nifH gene, respectively. The digestion products were analyzed using an automated sequencer (model 373A; Applied Biosystems, Weiterstadt, Germany) by the Sunny Company (Shanghai, China).

Table 1. Soil physicochemical properties and diversity of AM fungi and nitrogen-fixing bacteria in rhizosphere soils $(\operatorname{LSD} \leq 0.05 ; \mathrm{n}=3)$.

\begin{tabular}{|c|c|c|c|c|c|c|c|c|}
\hline \multirow{2}{*}{ Plant species } & $\begin{array}{c}\text { AP } \\
\left(\mathrm{g} . \mathrm{kg}^{-1}\right)\end{array}$ & $\begin{array}{c}\text { SOC } \\
\left(\mathrm{g} . \mathrm{kg}^{-1}\right)\end{array}$ & $\begin{array}{c}\text { TN } \\
\left(\mathrm{g} . \mathrm{kg}^{-1}\right)\end{array}$ & $\mathrm{pH}$ & \multicolumn{2}{|c|}{ Richness } & \multicolumn{2}{|c|}{ Evenness } \\
\cline { 6 - 9 } & & & & AM fungi & NFB & AM fungi & NFB \\
\hline L. chinense & $8.23 \pm 0.66 \mathrm{~b}$ & $57.78 \pm 2.12 \mathrm{~b}$ & $4.70 \pm 0.35 \mathrm{~b}$ & $7.47 \pm 0.16 \mathrm{a}$ & $15 \pm 1 \mathrm{a}$ & $9 \pm 1 \mathrm{a}$ & $0.92 \pm 0.02 \mathrm{a}$ & $0.77 \pm 0.03 \mathrm{~b}$ \\
\hline S. championii & $8.27 \pm 0.89 \mathrm{~b}$ & $59.41 \pm 6.61 \mathrm{~b}$ & $5.46 \pm 1.23 \mathrm{~b}$ & $7.53 \pm 0.14 \mathrm{a}$ & $13 \pm 3 \mathrm{a}$ & $9 \mathrm{a}$ & $0.88 \pm 0.03 \mathrm{a}$ & $0.86 \pm 0.02 \mathrm{a}$ \\
\hline A. trewioides & $8.74 \pm 0.76 \mathrm{~b}$ & $67.53 \pm 8.05 \mathrm{~b}$ & $5.87 \pm 1.26 \mathrm{~b}$ & $7.29 \pm 0.16 \mathrm{a}$ & $14 \mathrm{a}$ & $8 \pm 1 \mathrm{a}$ & $0.92 \pm 0.02 \mathrm{a}$ & $0.84 \pm 0.01 \mathrm{a}$ \\
\hline B. purpurea & $10.25 \pm 0.36 \mathrm{~b}$ & $80.44 \pm 12.44 \mathrm{~b}$ & $10.04 \pm 3.76 \mathrm{~b}$ & $7.11 \pm 0.20 \mathrm{a}$ & $12 \pm 1 \mathrm{a}$ & $9 \mathrm{a}$ & $0.89 \pm 0.04 \mathrm{a}$ & $0.88 \pm 0.01 \mathrm{a}$ \\
\hline P. punctatum & $12.6 \pm 0.37 \mathrm{~b}$ & $101.97 \pm 23.03 \mathrm{~b}$ & $10.11 \pm 2.73 \mathrm{~b}$ & $7.09 \pm 0.13 \mathrm{a}$ & $14 \pm 1 \mathrm{a}$ & $9 \mathrm{a}$ & $0.91 \pm 0.01 \mathrm{a}$ & $0.88 \pm 0.02 \mathrm{a}$ \\
\hline A. odoratissima & $20.81 \pm 6.23 \mathrm{a}$ & $224.99 \pm 82.14 \mathrm{a}$ & $20.39 \pm 8.02 \mathrm{a}$ & $7.19 \pm 0.37 \mathrm{a}$ & $13 \pm 1 \mathrm{a}$ & $9 \mathrm{a}$ & $0.90 \pm 0.01 \mathrm{a}$ & $0.89 \pm 0.79 \mathrm{a}$ \\
\hline F value & 9.40 & 8.07 & 4.45 & 0.74 & 0.86 & 0.78 & 0.64 & 3.64 \\
\hline P value & 0.001 & 0.002 & 0.016 & 0.61 & 0.54 & 0.58 & 0.67 & 0.03 \\
\hline
\end{tabular}

Values are means $\pm \mathrm{SE}$ of three replicates.

Within rows, means with the same letter do not differ significantly at $p<0.05$ (LSD)

SOC, soil organic carbon; TN, total nitrogen; NFB, nitrogen-fixing bacteria. 
Table 2. Primer sequences and corresponding citations.

\begin{tabular}{|c|c|c|}
\hline Primer & Primer sequence (5'-3') & References \\
\hline Geo11F & ACCTTGTTACGACTTTTACTTCC & Schwarzott [22] \\
\hline GeoA2R & CCAGTAGTCATATGCTTGTCTC & Santos-González [23] \\
\hline NS31 & TTGGAGGGCAAGTCTGGTGCC & Santos-González [23] \\
\hline AM1 & CTTTCCCGTAAGGCGCCGAA & Sato [24] \\
\hline AMV4.5NF & AAGCTCGTAGTTGAATTTCG & Sato [24] \\
\hline AMDGR & CCCAACTATCCCT ATTAATCAT & Poly [25] \\
\hline PolF & TGCGAYCCSAARGCBGACTC & Poly [25] \\
\hline PolR & ATSGCCATCATYTCRCCGGA & \\
\hline
\end{tabular}

Forward and reverse primers are indicated by the letters $\mathrm{F}$ and $\mathrm{R}$, respectively.

$\mathrm{Y}=\mathrm{C}$ or $\mathrm{T} ; \mathrm{S}=\mathrm{C}$ or $\mathrm{G} ; \mathrm{R}=\mathrm{A}$ or $\mathrm{G} ; \mathrm{B}=\mathrm{C}, \mathrm{G}$, or $\mathrm{T}$.

The size and relative abundance of terminal restriction fragments (T-RFs) were evaluated using Gene Scan 2.1 (Applied Biosystems). Peak areas of T-RFs that differed by \pm 2 bp were summed and considered as one fragment. The relative abundance (RA) of each T-RF was calculated as previously described [26]: where $n i$ represents the peak area of one distinct T-RF, and $\mathrm{N}$ is the sum of all peak areas in one sample. T-RFs that were $>50 \mathrm{bp}$ in length and with $\mathrm{RA}>1 \%$ in all three replicates were analyzed. Peaks with $\mathrm{RA}>5 \%$ were regarded as dominant T-RFs.

As Aldrich-Wolfe et al. [27] described, using database T-RFLP identified AM fungal and NFB species: (i) T-RFLP profiles of AM fungi were determined for our 454 pyrosequencing sequences that were submitted to the MG-RAST public database (http://metagenomics.anl.gov/) under ID 4540338.3. And (ii) T-RFLP profiles of NFB were determined for 40 nifH sequences from karst region (accession numbers KF859859 to KF859898).

\section{Quantification of 18S rRNA and nifH Genes}

Abundances of the AM fungal 18S rRNA gene and the NFB nifH gene were determined using qPCR (ABI 7900, Foster City, CA) with primers AMV4.5NF/ AMDGR and PolF/PolR, respectively. Although AMV4.5NF/AMDGR can amplify non-AM fungal sequences, more than $70 \%$ of sequences obtained from the 454 pyrosequencing with these primers belonged to AM fungi in karst region [28].

The $10-\mu \mathrm{L}$ reaction mixture contained $5 \mu \mathrm{L} 1 \times \mathrm{SYBR}$ Premix ExTaq, $0.2 \mu \mathrm{L}$ Rox (Takara Bio, Shiga, Japan), $0.2 \mu \mathrm{M}$ of each primer (Invitrogen, China), $1 \mu \mathrm{L}$ 5-ng DNA template, and $3.4 \mu \mathrm{L}$ sterilized water. The thermocycling protocol for the fungal 18S rRNA gene was $20 \mathrm{~s}$ at $95^{\circ} \mathrm{C}$, followed by 30 cycles of $10 \mathrm{~s}$ at $95^{\circ} \mathrm{C}, 15 \mathrm{~s}$ at $62^{\circ} \mathrm{C}$, and $15 \mathrm{~s}$ at $72^{\circ} \mathrm{C}$. The thermocycling protocol for the bacterial nifH gene was $20 \mathrm{~s}$ at $95^{\circ} \mathrm{C}$, followed by 5 cycles of $15 \mathrm{~s}$ at $95^{\circ} \mathrm{C}, 20 \mathrm{~s}$ at $64^{\circ} \mathrm{C}$, and
$15 \mathrm{~s}$ at $72^{\circ} \mathrm{C}$, then 35 cycles of $15 \mathrm{~s}$ at $95^{\circ} \mathrm{C}, 25 \mathrm{~s}$ at $60^{\circ} \mathrm{C}$, and $15 \mathrm{~s}$ at $72^{\circ} \mathrm{C}$.

A standard curve was established from a 10-fold dilution series $\left(10^{2}-10^{8}\right.$ copies $)$ of the plasmids containing the target gene fragment. The efficiency of real-time qPCRs was $98 \%$ for the AM fungal 18S rRNA and $103 \%$ for the NFB nifH gene, while the $\mathrm{R}^{2}$ value for the curves of both two genes were 0.99 . The qPCR assays were performed using four technical replicates per sample for all samples in one plate. A single, sharp peak was observed for the melt curves of each assay. Data analysis was performed automatically using the SDS 2.3 software included with the real-time qPCR system.

\section{Statistical Analyses}

Statistical analyses were performed using SPSS 19.0 for Windows (SPSS Inc., Chicago, IL). Differences were considered significant at $p<0.05$. Differences in soil physicochemical properties between plants were evaluated using least significant difference (LSD) analysis. Data that were not normally distributed were $\log _{(x+1)}$-transformed. Diversity indices of AM fungi and NFB were calculated using PC-ORD 5.0 (MJM Software Design, Gleneden Beach, OR). Relationships between soil physicochemical properties, and abundances of fungal and bacterial were evaluated using the Pearson product-moment correlation coefficient. Redundancy analysis (RDA) was used to analyze the effects of soil physicochemical characteristics on microbial community composition, in CANOCO 4.5 (Microcomputer Power, Inc., Ithaca, NY). Before the RDA analysis, detrended correspondence analysis (DCA; gradient length $<3$ ) was performed to confirm that the linear ordination method was appropriate for analyzing the T-RFLP data. Monte Carlo permutation tests were also used to compute statistical significance. The relationships between community composition of AM fungi and NFB were assessed based on Pearson's 


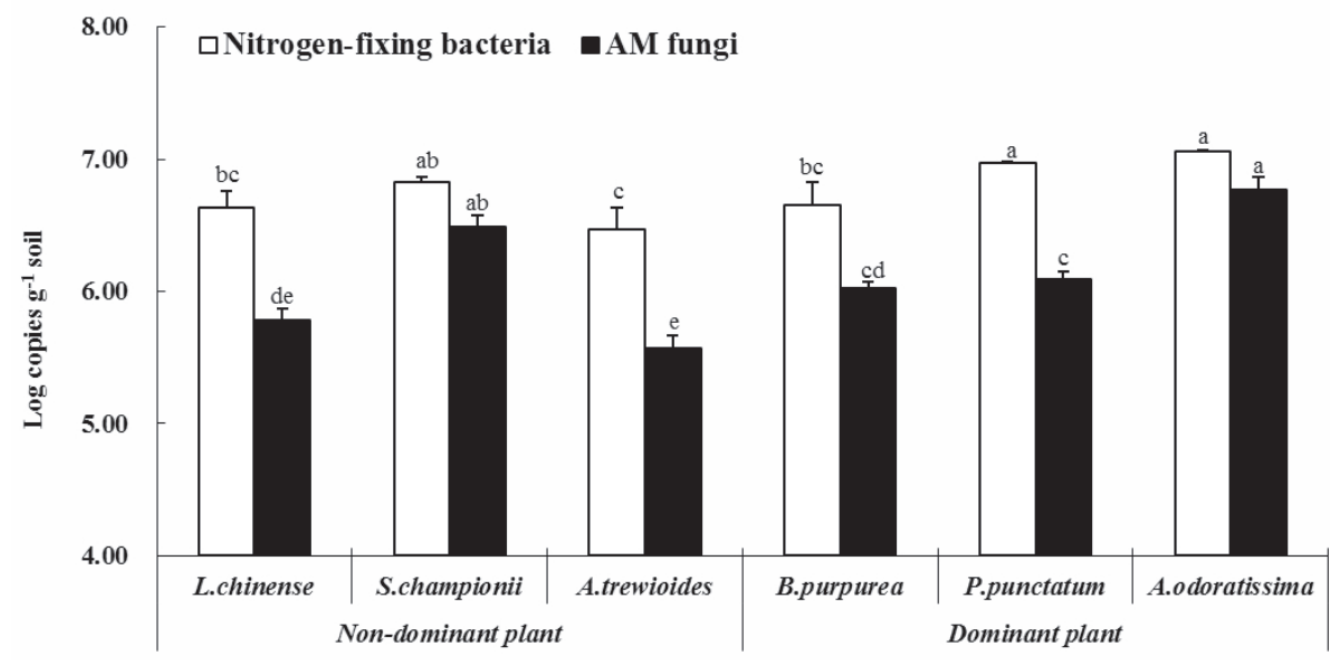

Fig. 1. Copy numbers for AM fungi and NFB in rhizosphere soils collected from different plant species. Different letters indicate significant differences between plants (LSD test; $p<0.05)$. Bars indicate $\mathrm{SE}(n=3)$.

correlations using Mantel tests with the Ecodist package in R software.

\section{Results}

\section{Abundance and Diversity of AM Fungi and NFB in Rhizosphere Soils}

The range of AM fungal abundance was 5.57 from to $6.77 \log$ copies $^{-1}$ soil, which varied among the plant rhizosphere soils (Fig. 1); A. odoratissima and $A$. trewioides exhibited the highest and lowest abundance, respectively. The evenness and richness indices of AM fungi were not significantly different among plants (Table 1).

The range of NFB abundance was 6.46 from to $7.05 \log$ copies $^{-1}$ soil, which varied among the plant rhizosphere soils (Fig. 1); again, A. odoratissima and $A$. trewioides exhibited the highest and lowest abundance, respectively. The evenness index of NFB was lower in $L$. chinense than in other plants, but the richness index was similar across all examined plants (Table 1).

\section{Composition and Structure of AM Fungal and NFB Community in Rhizosphere Soils}

We used 28 T-RFs in the ribotypes to analyze AM fungal community composition and structure in rhizosphere soils (Fig. 2a). There were 16, 14, 20, 14, 16, and 14 T-RFs for AM fungi from $L$. chinense, S. championii, A. trewioides, P. punctatum, B. acuminata, and $A$. odoratissima, respectively. Six T-RFs $(105,130$, $138,189,278$, and $300 \mathrm{bp}$ in length) were predominant in the rhizosphere soils of all plant species and accounted for $55 \%$ of all T-RFs, and the dominant $300 \mathrm{bpT}$-RF for AM fungi was the significantly different T-RFs among plants. Significant variation existed among the plant species in 27 AM fungal T-RFs (Fig. 2a). Although there are limitations to extrapolating species identities from T-RFs, the dominant 138-, 189-, and 278-bp T-RFs were closely related to Glomus sp. M20, Glomus sp. MUCL, and Glomus macrocarpum, respectively.

We obtained 13 T-RFs for NFB (Fig. 2b) and 11 T-RFs significantly differed among these soils; of these, 6, 7, 9, 7, 9, and 8 were found for $L$. chinense, S. championii, A. trewioides, P. punctatum, B. acuminata, and $A$. odoratissima, respectively. Five dominant T-RFs $(66,75,157,180$, and $184 \mathrm{bp})$ accounted for $80 \%$ of the NFB T-RFs in rhizosphere soils, and the dominant 180 bp T-RF for NFB was the significantly different T-RFs among plant soils. Our analyses indicated that the dominant 75, 157, 180, and 184-bp T-RFs were closely related to Bradyrhizobium sp. CCBAU 101065, Bradyrhizobium sp. ISA1601, Bradyrhizobium japonicum, and Bradyrhizobium sp. ISA0508, respectively.

\section{Effects of Host Plant and Soil Physicochemical Properties on Microbial Communities}

Results of the RDA revealed that the fungal community composition differed among plants, especially between $A$. odoratissima and the other plants (Fig. 3a). The NFB community composition had a similar distribution as AM fungi (Fig. 3b). These results indicated that host plant species had a strong effect on microbial community composition. Available phosphorus was significantly correlated with AM fungal $(\mathrm{F}=2.80, p=0.016)$ and NFB community composition ( $\mathrm{F}=4.80, p=0.002)$. Additionally, SOC and TN were significantly correlated with $\mathrm{AM}$ fungi (Fig. 3a; $\mathrm{F}=2.80, p=0.016$ and $\mathrm{F}=2.80, p=0.016$, respectively) and with NFB community composition (Fig. 3b; $\mathrm{F}=4.71, p=0.002$ and $\mathrm{F}=3.44, p=0.004$, respectively). 
The contents of available phosphorus, soil organic carbon, and total nitrogen were positively correlated to the AM fungal abundance $(p<0.05$, Table 3$)$. Similarly, the contents of soil organic carbon and available phosphorus were negatively correlated with the NFB abundance $(p<0.05$, Table 3$)$.

\section{Links between AM Fungi and NFB Communities in Rhizosphere Soils}

The Mantel test showed that AM fungal community composition was not significantly correlated with NFB community composition in rhizosphere soils $(\mathrm{r}=0.093$, $p=0.115$ ). However, RDA analysis found that the dominant 278-bp T-RF (Glomus macrocarpum) from AM fungi was highly correlated with the dominant 184-bp T-RF (Bradyrhizobium sp. ISA0508) from NFB. In addition, the 105-bp T-RF (uncultured Glomus) from AM fungi positively correlated with the 180-bp T-RF (Bradyrhizobium japonicum) from NFB (Fig. 4).

No significant correlation was found between the fungal and bacterial richness $(\mathrm{r}=0.110, p=0.661)$ or evenness ( $\mathrm{r}=-0.388, p=0.112)$ indices, but the abundances of AM fungi and NFB were highly
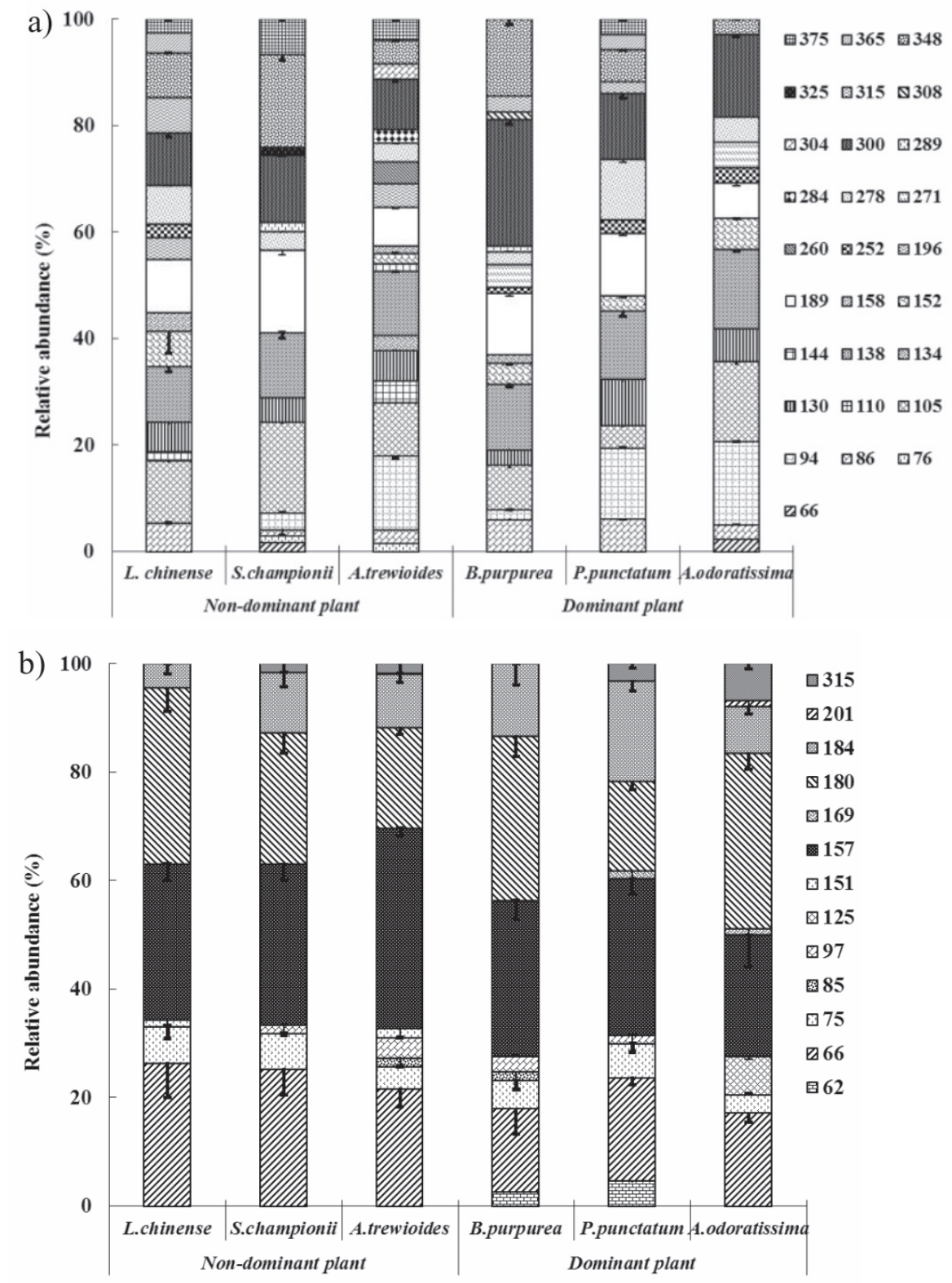

Fig. 2. Average relative abundance of AM fungi a) and NFB b) terminal restriction fragments (T-RFs) in rhizosphere soils of different plant species, as determined by endonuclease digestion with HinfI (fungi) and HaeIII (bacteria). The relative abundance of T-RFs is given as a percentage of the total peak area. Fragment sizes in the graph indicate the size of the experimental T-RFs. Bars indicate SE $(n=3)$. Among the plant species, 27 T-RFs $(66,76,86,94,105,110,130,134,138,144,158,189,196,252,260,271,278,284,289,300,304$, $315,325,348,365$, and $375 \mathrm{bp})$ from AM fungi and 11 T-RFs $(62,85,97,125,151,157,169,180,184,201$, and 315 bp) from NFB differed significantly. 
a)

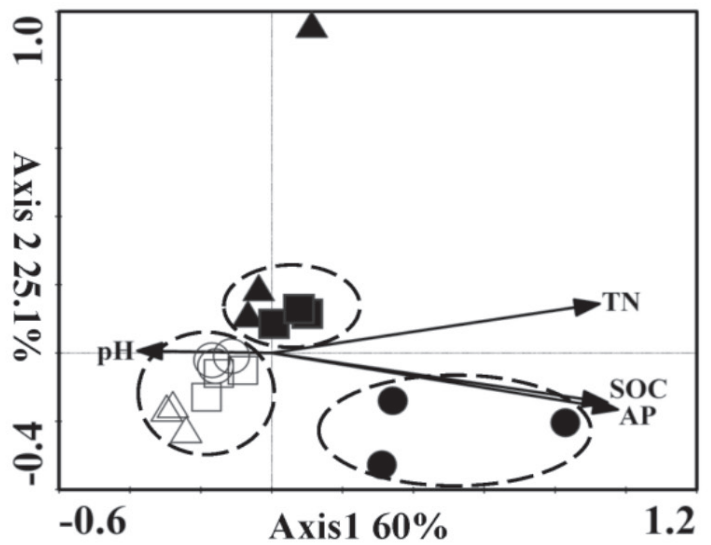

b)

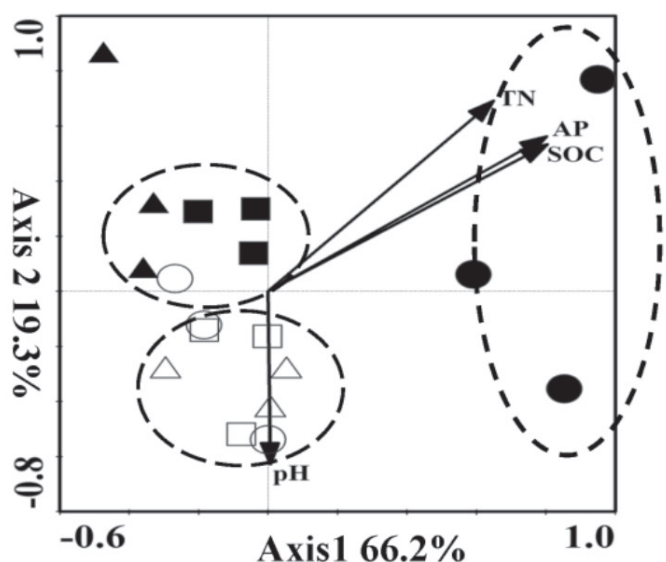

Fig. 3. Redundancy analysis (RDA) of terminal restriction fragment length polymorphism (T-RFLP) profiles for the AM fungal community a) and the NFB community b) in rhizosphere soils from different plant species. Arrows represent environmental variables. Open triangle, Loropetalum chinense; open square, Syzygium championii; open circle, Alchornea trewioides; solid triangle, Bauhinia acuminata; solid square, Pterolobium punctatum; solid circle, Albizia odoratissima. SOC, soil organic carbon; TN, total nitrogen; AP, available phosphorus.

Table 3. Pearson correlations between soil chemo-physical properties, AM fungal and NFB abundance in rhizosphere soils from different plant species $(\mathrm{n}=3)$.

\begin{tabular}{|c|c|c|}
\hline & $\begin{array}{c}\text { AM fungal } \\
\text { abundance }\end{array}$ & $\begin{array}{c}\text { NFB } \\
\text { abundance }\end{array}$ \\
\hline AP & $0.714^{\mathrm{a}}$ & $0.473^{\mathrm{b}}$ \\
\hline SOC & $0.777^{\mathrm{a}}$ & $0.505^{\mathrm{b}}$ \\
\hline TN & $0.672^{\mathrm{a}}$ & - \\
\hline
\end{tabular}

SOC, soil organic carbon; TN, total nitrogen;

${ }^{\text {a }}$ Correlation is significant at the 0.01 level (two-tailed);

${ }^{\mathrm{b}}$ Correlation is significant at the 0.05 level (two-tailed). correlated (Pearson's correlation; $\mathrm{R}^{2}=0.55, p<0.001$; Fig. 5).

\section{Discussion}

Effects of Host Plant Species and Soil Nutrients on Rhizosphere AM Fungal Community

AM fungi can improve soil nutrient content, thus, promoting plant growth, and studies have demonstrated that higher AM fungal colonization tends to increase soil nutrient contents [2, 29]. In the present case,

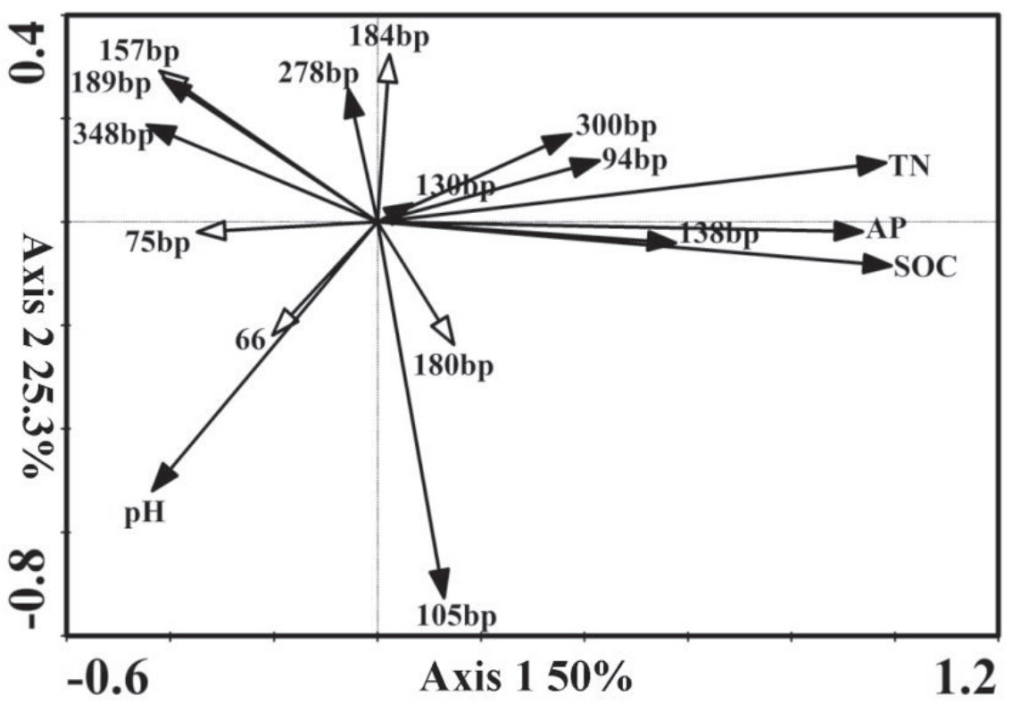

Fig. 4. Redundancy analysis (RDA) of terminal restriction fragment length polymorphism (T-RFLP) profiles for the relationship between dominant species of AM fungi and NFB in rhizosphere soils from different plant species. Solid arrows represent environmental variables and dominant AM fungal species. Hollow arrows represent dominant NFB species. SOC, soil organic carbon; TN, total nitrogen; AP, available phosphorus. 


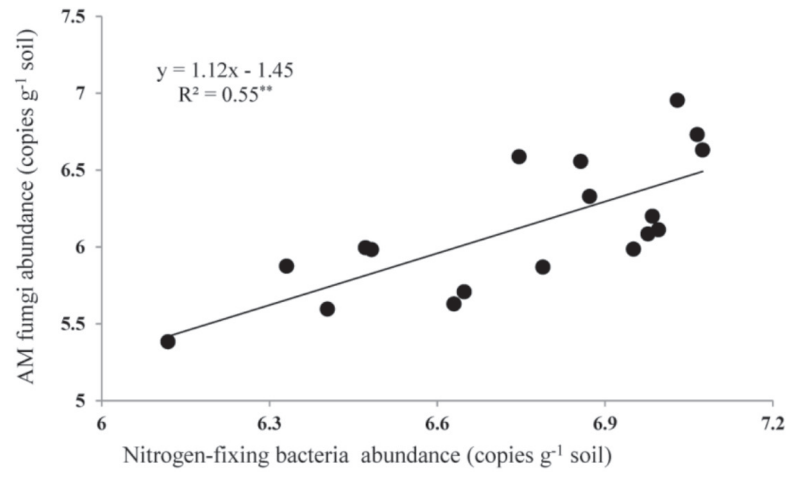

Fig. 5. Relationship between abundance of AM fungi and NFB in rhizosphere soils from studied plant species. Asterisks indicate significant correlations at $\alpha=0.01$. For data on microbial abundance, see Fig. 1.

AM fungal abundance was positively correlated with available phosphorus content as well as the contents of total nitrogen and soil organic carbon. Our result was not in agreement with the previous study by Gosling et al. [30]. Several explanations are possible for this inconsistent result. First, the soil nutrient content in the karst region may not have been lower than the threshold that leads to reducing AM fungal abundance. Second, other characteristics, such as soil structure, may alter how soil nutrients affect AM fungal diversity [31].

Fungal abundance varied among the plants and was higher in non-dominant plants than in dominant ones (except for $S$. championii). This outcome suggests that non-dominant species were more dependent on AM fungi in karst regions. Additionally, the AM fungal community composition varied across plants (Fig. 3a), suggesting the presence of host-plant specificity [32]. The previous study has found that specificity in AM fungi-plant interactions may occur more often on the level of plant functional groups than individual species [32]. While we did not address this possibility in the current study, future research will attempt to verify whether the relevance of plant functional groups also applies for fungi-plant relations in karsts.

Despite plant-specific variation in abundance, the dominant fungal taxon in all rhizosphere soils was Glomerales. This order is also dominant in many host plants from other regions [33, 34], likely to because these fungi can colonize plants from fragments of mycelium or mycorrhizal roots. Compared with other taxa, Glomerales appear to be more flexible and can better adapt to a range of environments [34, 35], including karst regions [28].

The richness of AM fungi did not vary significantly among rhizosphere soils. This outcome is likely due to the ability of AM fungal species to form symbioses with several host plant species [36], even when they have host-plant preferences. As a result, the richness of AM fungi is generally lower and less variable compared with host plant richness: approximately 100 species of AM fungi have been described based on morphology, versus more than 100000 terrestrial plant species $[37,38]$. We obtained lower AM fungal richness than other studies that used the same methods [39]. This disparity may due to variation in the degree of fungal interspecific competition across the different study sites. In our study, we found six predominant T-RFs for AM fungi associated with all of the plant species. These dominant species suppress the growth of non-dominant species, thus reducing and homogenizing total microbial richness across rhizospheres.

\section{Effects of Host Plant Species and Soil Nutrient Content on NFB in the Rhizosphere}

The abundance of NFB was higher in the rhizospheres of non-dominant plants than dominant plants (except for $S$. championii). We believe this result is likely due to differences in soil properties between the rhizospheres of non-dominant versus dominant plants. Among soil properties, soil carbon availability especially affects NFB abundance [40]. Thus, higher soil carbon availability in the rhizosphere of nondominant plants can improve growth and survival of NFB, increasing their abundance.

Among the non-dominant legume plants, bacterial abundance was highest in the $S$. championii rhizosphere, which also exhibited high AM fungal abundance. Previous research has found that AM fungi enhance the nutrient-uptake capacity and thus the abundance of NFB [41], explaining our results. Therefore, plant speciesdependent variation in soil nutrients and the presence of AM fungi may be the major factors influencing the abundance of NFB.

Host plants also have a great effect on the NFB community composition [18]. Plants affect microbial community composition mainly through the composition and concentration of root exudates [42, 43]. Root exudates influenced soil available phosphorus and further had great effect on bacterial community composition, corroborating previous results [44, 45]. Despite bacterial community composition variation in all rhizosphere soils, the dominant bacterial taxon was the genus Bradyrhizobium. This genus is widely distributed in China [46, 47], and typically prevalent in high-pH soils [39].

\section{Relationships between AM Fungi and NFB in Rhizosphere Soils}

Despite numerous studies on the topic, researchers disagree about the nature of interactions between AM fungi and NFB [1, 48]. Here, we found significant correlations between the dominant T-RFs of AM fungi and NFB (Fig. 4), implying that these microorganismsexhibit similar preferences for host-plant species. One possible explanation for this preference is that species-specific exudates from AM fungi may activate particular NFB species, resulting in selective and stable cooperation between distinct species of both microbial 
taxa on the same host plant. This interaction can help explain why different effects on plant growth were observed in co-inoculation experiments with AM fungi and NFB $[2,9,10]$. We suggest that the compatibility of fungi and bacterial communities should be considered when targeting plants for co-inoculation as a means of restoring vegetation in karst regions.

We found a concurrent increase in the abundance of AM fungi and NFB (Fig. 5), supporting the close relationship of the two taxa. Their combined effects on plant growth may explain the concurrent increase. AM fungi enhances phosphorus uptake [49], and phosphorus is essential for bacterial $\mathrm{N}$-fixation and further leads to their increased abundance [6]. This increase in available nitrogen then serves to improve plant metabolism and productivity. As a result, plants are able to provide large quantities of carbohydrates to AM fungi, increasing fungal abundance in a positive feedback loop [39]. If this interaction occurs in the low-nutrient karst soils, then the observed positive correlation between AM fungal and NFB abundance is probably important to vegetation restoration in the karst region. While our findings have potential applications for all nutrientpoor soils, further study is needed to determine whether the relationship between fungal and NFB abundances occurs in other regions.

\section{Conclusions}

In conclusion, the composition of AM fungal and NFB communities varied among plant species and was closely related to soil properties (total nitrogen, soil organic carbon, and available phosphorus). Fungal and bacterial taxonomic abundance increased concurrently. Moreover, these microbes are similar in their host-plant specificity. Therefore, inoculating plants with compatible species of AM fungi and NFB should promote target plant growth and establishment, improving the success of vegetation restoration. However, limitations inherent to the T-RFLP analysis meant we could not definitively identify which microbial taxon was dominant in soil. Thus, future studies aiming to characterize AM fungal and NFB communities should combine morphological and molecular methods.

\section{Acknowledgments}

This project was supported by the National Natural Science Foundation of China (grant number U20A2011, 31870503, 41907208, 31800441), the Natural Science Foundation of Guangxi (grant numbers 2017GXNSFAA198241，2018GXNSFBA138012) and Special fund projects of central government guiding local science and technology development (Guike ZY20198012).

\section{Conflicts of Interest}

The authors declare no conflict of interest.

\section{References}

1. VAN HEIJDEN M.G., DE BRUINruin S., LUCKERHOFF L., VAN LOGESTIJIN R.S., SCHLAEPPI K. A widespread plant-fungal-bacterial symbiosis promotes plant biodiversity, plant nutrition and seedling recruitment. ISME J. 10, 389, 2016.

2. KAVADIA A., OMIROU M., FASOULA D.A., LOUK F., EHALIOTIS C., IOANNIDES I.M. Co-inoculations with rhizobia and arbuscular mycorrhizal fungi alters mycorrhizal composition and lead to synergistic growth effects in cowpea that are fungal combination-dependent. Appl. Soil Ecol. 167, 104013, 2021.

3. PRIMIERI S., SANTOS J.C.P., ANTUNES P.M. Noduleassociated bacteria alter the mutualism between arbuscular mycorrhizal fungi and $\mathrm{N}_{2}$ fixing bacteria. Soil Biol. Biochem. 154, 108149, 2021.

4. RILLING M.C., MUMMEY D.L. Mycorrhizas and soil structure. New Phytol. 171, 41, 2006.

5. YANG H., ZHANG Q., KOIDE R.T., HOEKSEMA J.D., TANG J., BIAN X., HU S., CHEN X., Taxonomic resolution is a determinant of biodiversity effects in arbuscular mycorrhizal fungal communities. J. Ecol. 105, 219, 2017.

6. MORTIMER P.E., LE ROUR M.R., PÉREZFERNÁNDEZ M.A., BENEDITO V.A., KLEINERT A., XU J.C., VALENTINE A.J. The dual symbiosis between arbuscular mycorrhiza and nitrogen fixing bacteria benefits the growth and nutrition of the woody invasive legume Acacia Cyclops under nutrient limiting conditions. Plant Soil 366, 229, 2013.

7. PEREIRA S., MUCHA A., GONCALXEC B., BACELAR E., LATR A., FERREIRA H., OLIVEIRA I., ROSA E., MARQUES G. Improvement of some growth and yield parameters of faba bean (Vicia faba) by inoculation with Rhizobium laguerreae and arbuscular mycorrhizal fungi. Crop Pasture Sci. 70, 595, 2019.

8. LARIMER A.L., CLAY1 K., BEVER J.D. Synergism and context dependency of interactions between arbuscular mycorrhizal fungi and rhizobia with a prairie legume. Ecology 95,1045, 2014.

9. BALLORN D.J., SCHADLER M., ELIAS J.D., MILLAR J.A., KAUTA S. Friend or foe-light availability determines the relationship between mycorrhizal fungi, rhizobia and lima bean (Phaseolus lunatus L.). PLoS One 11, e154116, 2016.

10. PÜSCHEL D., JANOUSKOVA M., VORISKOA A., GRYNDLEROVA H., VOSATKA M., JANSA J. Arbuscular mycorrhiza stimulates biological nitrogen fixation in two Medicago spp. through improved phosphorus acquisition. Front. Plant Sci. and restoration. Earth-Sci. Rev. 132, 1, 2017.

11. ZHU T.B., ZENG S.M., QIN H.L., ZHOU K.X., YANG H., LAN F.N., HUANG F., CAO J.H., MÜLLER C. Low nitrate retention capacity in calcareous soil under woodland in the karst region of southwestern China. Soil Biol. Biochem. 97, 99, 2016.

12. XIAO S., ZHANG W., YE Y., ZHAO J., WANG K. Soil aggregate mediates the impacts of land uses on organic 
carbon, total nitrogen, and microbial activity in a Karst ecosystem. Sci. Rep.-UK. 7, 10, 2017.

13. YE Y.Y., XIAO S.S., LIU S.J., ZHANG W., ZHAO J., CHEN H.S., GUGGENBERGER G., WANG K.L. Tillage induces rapid loss of organic carbon in large macroaggregates of calcareous soils. Soil Till. Res. 199, 104549, 2020.

14. JIANG Z.C., LIAN Y.Q., QIN X.Q. Rocky desertification in Southwest China: impacts, causes, and restoration. Earth-Sci Rev 132, 1, 2014.

15. WANG S.J., LIU Q.M., ZHANG D.F. Karst rocky desertification in southwestern China, geomorphology, landuse, impact and rehabilitation. Land Degrad. Dev. 15, 115, 2004.

16. TONG T.W., BRANDT M., YUE Y.M., HORION S., WANG K.L., KEERSMAECKER W.D., TIAN F., SCHURGERS G., XIAO X.M., LUO Y.Q., CHEN C., MYNENI R.G., SHI Z., CHEN H.S., FENSHOLT R. Increased vegetation growth and carbon stock in China karst via ecological engineering. Nature Sustaianbility 1, 44, 2018

17. LIANG Y.M., HE X.Y., CHEN X.B., HU Y.J., SU Y.R. Nitrogen-fixing bacterial communities exhibit strong spatial structure along a slope gradient in karst shrublands ecosystem. Pol. J. Environ. Stud. 28, 3369, 2019.

18. LIU L., HE X.Y., WANG K.L., XIE Y.J., XIE Q., O'DONNELL A.G., CHEN C.Y. The Bradyrhizobiumlegume symbiosis is dominant in the shrubby ecosystem of the Karst region, Southwest China. Eur. J. Soil Biol. 68, $1,2015$.

19. BELL C., CARRILlO Y., BOOT C.M., ROCCA J.D., PENDALL E., WALLENSTEIN M.D. Rhizosphere stoichiometry: are C:N:P ratios of plants, soils, and enzymes conserved at the plant species-level? New Phytol. 201, 505, 2014.

20. BREMNER J.M. Total nitrogen. In: Black CA (ed) Methods of soil analysis. American Society of Agricultural, 2. USA, 1149, 1965.

21. COLWELL J.D. The estimation of phosphorus fertilizer requirements of wheat in southern New South Wales by soil analysis. Aust. J. Exp. Agric. Anim. Husb. 3, 190, 1963.

22. SCHWARZOTT D., SCHÜSSLER A. A simple and reliable method for SSU rRNA gene DNA extraction, amplification, and cloning from single AM fungal spores. Mycorrhiza 10, 203, 2001.

23. SANTOS-GONZÁLEZ J.C., FINLAY R.D., TEHLERS A. Seasonal dynamics of arbuscular mycorrhizal fungal communities in roots in a seminatural grassland. Appl. Environ. Microbiol. 17, 5613, 2007.

24. SATO K., SUYAMA Y., SAITO M., SUGAWARA K. A new primer for discrimination of arbuscular mycorrhizal fungi with polymerase chain reaction-denature gradient gel electrophoresis. Grassl. Sci. 51, 179, 2005.

25. POLY F., RANJARD L., NAZARET S., GOURBIERE F., MONROZIER L.J. Comparison of nifH gene pools in soils and soil microenvironments with contrasting properties. Appl. Environ. Microbiol. 67, 2255, 2001.

26. LUKOW T., DUNFIELD P.F., LIESACK W. Use of the T-RFLP technique to assess spatial and temporal changes in the bacterial community structure with in an agricultural soil planted with transgenic and no transgenic potato plants. FEMS Microbiol Ecol. 32, 241, 2000.

27. ALDRICH-WOLFE L. Distinct mycorrhizal communities on new and established hosts in a transitional tropical plant community. Ecology 88, 559, 2007.
28. LIANG Y.M., HE X.Y., CHEN C.Y., FENG S.Z., LIU L., CHEN X.B., SU Y.R. Influence of plant communities and soil properties during natural vegetation restoration on arbuscular mycorrhizal fungal communities in a karst region. Ecol. Eng. 82, 57, 2015.

29. INGRAFFIA R., AMATO G., FRENDA A.S., GIAMBALVO D. Impacts of arbuscular mycorrhizal fungi on nutrient uptake, $\mathrm{N}_{2}$ fixation, $\mathrm{N}$ transfer, and growth in a wheat/faba bean intercropping system. PLoS One 14, e0213672, 2019.

30. GOSLING P., MEAD A., PROCTOR M., HAMMOND J.P., BENDING G.D. Contrasting arbuscular mycorrhizal communities colonizing different host plants show a similar response to a soil phosphorus concentration gradient. New Phytol. 198, 546, 2013.

31. ZHANG Z.F., MALLIK A., ZHANG J.C., HUANG Y.Q., ZHOU L.W. Effects of arbuscular mycorrhizal fungi on inoculated seedling growth and rhizosphere soil aggregates. Soil Till. Res. 194,104340, 2019.

32. ÖPIK M., METSIS M., DANIELL T.J., ZOBEL M., MOORA M. Large-scale parallel 454 sequencing reveals host ecological group specificity of arbuscular mycorrhizal fungi in a boreonemoral forest. New Phytol. 18, 424, 2009.

33. SÁNCHEZ-CASTRO I., GIANINAZZI-PEARSON C., CLEYET-MAREL J.C., BAUDOIN E., VAN TUINEN D. Glomeromycota communities survive extreme levels of metal toxicity in an orphan mining site. Sci. Total Environ. 598, 121, 2017.

34. BALTRUSCHAT H., SANTOS V.M., SILVA D.K.A., SCHELLENBERG I., DEUBEL A., SIEVERDING E., OEHL F. Unexpectedly high diversity of arbuscular mycorrhizal fungi in fertile Chernozem croplands in Central Europe. Catena 182, 104135, 2019.

35. ZHU C., LING N., WANG M., GUO J., SHEN O. Impact of fertilization regimes on arbuscular mycorrhizal fungal (AMF) community composition were correlated with organic matter composition in maize rhizosphere soil. Front. Microbiol. 7, 1, 2016.

36. DAVISON J., ÖPIK M., DANIELL T.J., MOORA M., ZOBEL M. Arbuscular mycorrhizal fungal communities in plant roots are not random assemblages. FEMS Microbiol. Ecol. 78, 103, 2011.

37. CHEN M., ARATO M., BORGHI L., NOURI E., REINHARDT D. Beneficial services of arbuscular mycorrhizal fungi-from ecology to application. Front. Plant. Sci. 9, 1270, 2018.

38. MELO C.D., WALLER C., KRüGER C., BORGES P.A.V., LUNA S., MENDONCA D., FONSECA H.M.A.C., MACHADO A.C. Environmental factors driving arbuscular mycorrhizal fungal communities associated with endemic woody plant Picconiaazorica on native forest of Azores. Ann. Microbiol. 69, 1309, 2019.

39. UIBOPUU A., MOORA M., SAKS Ü., DANIELL T., ZOBEL M., ÖPIK M. Differential effect of arbuscular mycorrhizal fungal communities from ecosystems. Soil Biol. Biochem. 41, 2141, 2009.

40. XIAO D., TAN Y.J., LIU X., YANG R., ZHANG W., HE X.Y., XU Z.H., WANG K.L. Responses of soil diazotrophs to legume species and density in a karst grassland, southwest China. Agr. Ecosyst. Environ. 288, 106707, 2020.

41. NASTO M.K., ALVAREZ-CLARE S., LEKBERG Y., SULLIVAN B.W., TOWNSEND A.R., CLEVELAND C.C. Interactions among nitrogen fixation and soil phosphorus 
acquisition strategies in lowland tropical rain fores. Ecol. Lett. 17, 1282, 2014.

42. ZHALNINA K., LOUIE K.B., HAO Z., MANSOORI N., da ROCHA U.N., SHI S., CHO H., KARAOZ U., LOQUE D., BOWEN B.P., FIRESTONE M.K., NORTHEN T.R., BRODIE E. L. Dynamic root exudate chemistry and microbial substrate preferences drive patterns in rhizosphere microbial community assembly. Nat. Microbiol. 3, 470, 2018.

43. ZWETSLOOT M.J., UCROS J.M., WICKINGS K., WILHELM R.C., SPARKS J., BUCKLEY D.H., BAUERLE T.L. Prevalent root-derived phenolics drive shifts in microbial community composition and prime decomposition in forest soil. Soil Biol. Biochem. 145, 107797, 2020.

44. WEI X.M., HU Y.J., RAZAVI B.S., ZHOU J., SHEN J.L., NANNIPIERI P., WU J.S., GE T.D. Rare taxa of alkaline phosphomonoesterase-harboring microorganisms mediate soil phosphorus mineralization. Soil Biol. Biochem. 131, 62, 2019.

45. LIANG Y.M., LI M.J., PAN F.J., MA J.M., YANG Z.Q., LING T.W., QIN J.H., LU S.H., ZHONG F.Y., SONG Z.R. Alkaline phosphomonoesterase-harboring microorganisms mediate soil phosphorus transformation with stand age in Chinese Pinus massoniana plantations. Front. Microb. 27, 571209, 2020.

46. FENG M., ADAMS J.M., FAN K., SHI Y., SUN R., WANG D., GUO X., CHU H. Long-term fertilization influences community assembly processes of soil diazotrophs. Soil Biol. Biochem. 126, 151, 2018.

47. CHEN L., LI K.K., SHI W.J., LIN WANG X.L., WANG E.T., LIU J.F., SUI X.H., MI G.H., TIAN C.F., CHEN W.X. Negative impacts of excessive nitrogen fertilization on the abundance and diversity of diazotrophs in black soil under maize monocropping. Geoderma 393, 114999, 2021.

48. ABD-ALLA M.H., EL-ENANY A.W.E., NAFADY N.A., KHALAF D.M., MORSY F.M. Synergistic interaction of Rhizobium leguminosarum bv. viciae and arbuscular mycorrhizal fungi as a plant growth promoting biofertilizers for faba bean (Vicia faba $L$.) in alkaline soil. Microbiol. Res.169, 49, 2014.

49. YANG H.S., YU Z.X., ZHANG Q., TANG J.J., CHEN $X$. Plant neighbor effects mediated by rhizosphere factors along a simulated aridity gradient. Plant Soil 369, 165, 2013. 
